\title{
KOMPARASI KEMAMPUAN PEMECAHAN MASALAH MATEMATIKA ANTARA PMR DAN PBM PADA MATERI GEOMETRI SMP KELAS VII
}

\author{
I Wayan Amperawan ${ }^{1 *}$, I Gusti Ngurah Pujawan ${ }^{2)}$, I Made Suarsana ${ }^{3)}$ \\ Prodi Pendidikan Matematika, FMIPA, Universitas Pendidikan Ganesha, Singaraja, 81117 \\ *suarsana1983@gmail.com
}

\begin{abstract}
Abstrak
Penelitian ini bertujuan untuk mengetahui apakah kemampuan pemecahan masalah matematika siswa yang dibelajarkan menggunakan pembelajaran matematika realistik (PMR) lebih baik daripada siswa yang dibelajarkan dengan pembelajaran berbasis masalah (PBM). Jenis penelitian ini adalah eksperiman semu dan menggunakan desain penelitian adalah Post-test Only Control Group Design. Populasi dalam penelitian ini adalah siswa kelas VII non unggulan di SMP N 1 Sukasada pada tahun ajaran 2017/2018. Siswa pada kelompok eksperimen dibelajarkan dengan pembelajaran matematika realistik dan pada kelompok pembanding dibelajarkan dengan PBM selama 8 kali pertemuan, serta pada pertemuan ke-9 dilaksanakan post-test. Post-test pada penelitian ini menggunakan tes pemecahan masalah matematika yang berbentuk tes uraian. Melalui tes tersebut diperoleh rata-rata skor kelompok eksperimen sebesar 13,43 dan kelompok pembanding sebesar 12,37. Perolehan data dalam penelitian tersebut diuji normalitasnya menggunakan uji liliefors, homogenitas penelitian diuji dengan uji levene dan hipotesis penelitian diuji dengan uji-t. Dari analisis data diperoleh $t_{\text {hitung }}=1,76959$ dan $t_{(1-\alpha)(d k)}=1,672$. Apabila dibandingkan, nilai $t_{\text {hitung }} \geq t_{(1-\alpha)(d k)}$ sehingga $H_{0}$ ditolak. Berdasarkan analisis tersebut maka dapat disimpulkan kemampuan pemecahan masalah matematika siswa yang dibelajarkan dengan pembelajaran matematika realistik lebih baik daripada kemampuan pemecahan masalah matematika siswa yang dibelajarkan dengan pembelajaran berbasis masalah.
\end{abstract}

Kata Kunci:. PMR, PBM, Kemampuan Pemecahan Masalah.

\section{PENDAHULUAN}

Pembelajaran matematika merupakan salah satu bagian dari pembelajaran di sekolah, di mana matematika memiliki peranan penting dalam men- ingkatkan penalaran dan membentuk karakter dari peserta didik, serta untuk dapat meningkatkan kemampuan penerapan matematika dalam permasalahan sehari-hari. Aktivitas pembelajaran mate- 
matika akan membentuk nalar yang diperlukan oleh peserta didik agar mampu berpikir secara rasional, kritis, objektif, cermat, dan bersifat terbuka dalam melakukan pemecahan masalah sehari-hari yang berkaitan dengan matematika (Murniati, 2013). Matematika itu sendiri adalah sebuah disiplin ilmu yang berfokus kepada tata cara berpikir dan mengelola logika, baik itu secara kuantitatif maupun secara kualitatif (Mahayukti,dkk.2013). Suherman (2003) menyatakan bahwa pembelajaran matematika merupakan hal yang penting yang bertujuan untuk membentuk siswa agar (1) mampu dalam menerapkan matematika sebagai alat dalam memecahkan permasalahan matematika yang dihadapkan; (2) mampu menjadikan matematika sebagai suatu alat komunikasi; (3) mampu menggunakan matematika sebagai koneksi dan alat dalam bernalar.

Berdasarkan pemikiran tersebut, maka matematika dapat dianggap sebagai ilmu dasar yang harus dipelajari dari sekolah dasar hingga perguruan tinggi. Pembelajaran matematika yang dilakukan sejak sekolah dasar diharapkan memberikan peluang yang lebih besar bagi siswa, agar dapat lebih baik dalam memahami pembelajaran matematika. Selain itu peningkatan sarana prasarana penunjang dalam proses pembelajaran matematika, perbaikan kurikulum, dan sertifikasi guru mata pelajaran matematika juga telah dilakukan agar hal tersebut dapat berdampak kepada proses pembelajaran matematika nantinya.

Berbagai usaha yang dilakukan tersebut ternyata belum bisa menjawab setiap permasalahan pembelajaran matematika, hal ini dibuktikan dengan ratarata nilai ujian nasional matematika SMP tahun pelajaran 2016/2017 diseluruh Bali yaitu 43,63 atau mengalami penurunan dari sebelumnya yaitu 46,55. Sedangkan untuk kabupaten Buleleng juga mengalami penurunan yaitu dari 39,78 pada tahun pelajaran 2015/2016 menjadi 32,23 pada tahun 2016/2017 (Kemendikbud, 2017). Berdasarkan data tersebut nampak bahwa skor ujian nasional matematika di Bali dan di Buleleng mengalami penurunan, sedangkan seperti yang kita ketahui pemerintah telah melakukan berbagai upaya untuk meningkatkan kualitas pendidikan di Indonesia. Namun hal tersebut berbanding terbalik dengan skor ujian nasional yang dihasilkan. Selain itu juga berdasarkan data hasil observasi dan wawancara dengan guru mata pelajaran matematika kelas VII di SMP N 1 Sukasada yang menyatakan bahwa skor ulangan umum semester ganjil matematika siswa sebagian besar masih di bawah KKM yang ditetapkan. Berdasarkan hal tersebut maka dapat diketahui bahwa pembelajaran yang selama ini dilaksanakan masih belum bisa mempengaruhi kemampuan pemecahan masalah, pemahaman konsep, dan kemampuan berpikir tingkat tinggi siswa, sedangkan seperti yang dipaparkan di atas matematika memiliki peranan yang sangat besar dalam kehidupan sehari-hari dan untuk dapat bersaing pada era globalisasi ini.

Pembelajaran matematika selama ini secara umum masih menggunakan pendekatan mekanistik dan strukturalistik pada jenjang Pendidikan Dasar dan Menengah (Bedilius, 2016). Di mana pendekatan mekanistik hanya menekankan pembelajaran berdasarkan apa yang diketahui oleh seorang pengajar, sedangkan pendekatan strukturalistik merupakan pendekatan di mana siswa hanya ditekankan pada ranah simbol dan keterkaitan dari struktur materi yang dibelajarkan saja. 
Pendekatan tersebut tidak menekankan ke matematisasi secara vertikal maupun matematisasi secara horizontal sehingga siswa belajar matematika hanya berdasarkan pengertian. Pemilihan metode pembelajaran yang tidak tepat menyebabkan siswa akan menjadi lebih sulit dalam memahami pelajaran matematika, sehingga berdampak kepada siswa yang akan mengalami kesulitan dalam proses pembelajaran matematika nantinya (Winarni,2013). Selain itu orientasi pembelajaran hanya pada buku teks akan cenderung mengarah kedominasi guru pada saat proses pembelajaran sehingga akan berdampak kepada siswa menjadi tidak aktif dalam pelaksanaan pembelajaran. Pembelajaran seperti ini tidak mengajarkan siswa agar dapat berpikir mandiri, memotivasi diri, dan meningkatkan kemampuan dalam memecahkan masalah.

\section{Lenchner (Hartono, 2014:3)} menyatakan bahwa pemecahan masalah matematika adalah "suatu proses dalam menerapkan pengetahuan matematika yang diperoleh ke dalam situasi baru yang belum dikenal". Berdasarkan pengertian tersebut maka pemecahan masalah matematika akan memiliki dampak kepada kemampuan matematika yang lain seperti pemahaman konsep matematika, penalaran matematika, dan komunikasi matematika, sehingga dapat dikatakan bahwa kemampuan pemecahan masalah siswa dapat menjadi sebuah indikator untuk mengetahui keberhasilan proses pembelajaran. Hasil pemecahan masalah dapat menjadi indikator keberhasilan dalam proses pembelajaran matematika, sehingga menghadirkan permasalahan-permasalahan dalam pembelajaran matematika merupakan sebuah keharusan (Sawyer, 1991).
Kemampuan pemecahan masalah menurut Dahar (1989) merupakan kesanggupan individu dalam menggabungkan berbagai konsep, aturan, serta prinsip yang telah mereka pelajari sebelumnya guna untuk menyelesaikan suatu persoalan. Upaya dalam yang dapat dilakukan dalam mempengaruhi kemampuan pemecahan masalah siswa adalah dengan mengikutsertakan siswa secara aktif dalam pembelajaran matematika adalah dengan menghadirkan matematika berdasarkan pengalaman dan dikaitkan dengan permasalahan sehari - hari siswa, dan dengan menjadikan matematika sebuah aktivitas di mana siswa diberikan sebuah kesempatan untuk belajar melakukan pemecahan masalah pada topik bahasan matematika sehingga pelajaran matematika menjadi lebih bermakna. Pembelajaran yang bermakna, diharapkan dapat membuat siswa bisa mengikuti pembelajaran dengan aktif dan dapat menangkap pembelajaran yang diberikan oleh guru sehingga diharapkan dapat mempengaruhi kemampuan pemecahan masalah matematika siswa.

Upaya untuk dapat mempengaruhi kemampuan pemecahan masalah matematika siswa maka dipandang perlu untukmenerapkan sebuah pembelajaran yang dapat membantu siswa dalam memahami materi pembelajaran, aktif dalam pelaksanaan pembelajaran, dapat memotivasi siswa dan menghadirkan aplikasi dari materi yang dibelajarkan dalam kehidupan sehari-hari. Pembelajaran dikatakan berkualitas jika pembelajaran itu bermakna, menantang usaha belajar, menuntut keaktifan siswa dan terintegrasi. Pembelajaran yang bermakna akan membuat siswa menjadi aktif, dan dapat mempengaruhi kemampuan pemecahan 
masalah matematika nantinya. Pembelajaran matematika akan lebih bermakna bagi siswa jika guru mampu menghadirkan permasalahan yang sering ditemui oleh siswa dalam kehidupan seharihari selain itu permasalahannya juga bisa diambil dari masalah yang dapat dibayangkan oleh siswa, sehingga siswa lebih mudah dalam memahami matematika (Suharta, 2017). Secara garis besar terdapat dua pembelajaran matematika yang menghadirkan permasalahan pada proses pembelajarannya yaitu problem based learning (PBM) dan pembelajaran matematika realistik (PMR).

Problem based learning atau yang lebih dikenal dengan pembelajaran berbasis masalah merupakan model pembelajaran yang diawali dari pemberian masalah nyata sebagai titik awal dalam pembelajaran sehingga siswa memperoleh konsep yang diinginkan melalui masalah tersebut. Hal yang senada juga diungkapkan oleh Arends (2007:381) yang menyatakan bahwa " $P B L$ lessons are organized around real life situations that evade simple answer and invite competing solution". Dalam proses pelajaran menggunakan PBM guru harus dapat menghadirkan berbagai permasalahan nyata dalam kehidupan sehari-hari siswa, di mana permasalahan tersebut dikondisikan agar dapat memberikan banyak solusi, sehingga implikasi dari hal tersebut, dalam pembelajaran berbasis masalah harus dapat melibatkan siswa dalam proses memecahkan masalah melalui pengintegrasian berbagai konsep dan prinsip dari berbagai ilmu. Siswa akan dituntut untuk dapat menyelesaikan permasalahan yang disajikan dalam proses pembelajaran dan yang lebih penting agar siswa dapat menjadi pembelajar yang mandiri. Guru disini hanya berperan sebagai pemberi permasalahan, pembimbing, serta mencatat setiap hasil pemecahan masalah siswa sehingga dapat dievaluasi nantinya. Pemberian masalah di awal akan mendorong siswa agar dapat berpikir lebih kompleks mengenai konsep yang dibelajarkan selain itu juga akan melatih pikiran tingkat tinggi siswa. Pembelajaran berbasis masalah akan cendrung berpusat kepada siswa dan menuntut keaktifan siswa dalam proses memecahkan masalah, hal ini akan memiliki pengaruh terhadap kemampuan pemecahan masalah dari siswa nantinya.

Pembelajaran matematika realistik merupakan pembelajaran yang menjadikan matematika sebagai aktivitas, membawa pengalaman sehari-hari ke dalam proses pembelajaran matematika serta mengaitkan setiap masalah matematika ke masalah sehari-hari atau dapat dibayangkan siswa (Suharta, 2017). Pada pembelajaran ini siswa diajak untuk menyelesaikan masalah yang mungkin atau bahkan sering dialami oleh siswa dalam kehidupannya, sehingga permasalahan matematika yang disajikan harus dekat dengan pengalaman dan kehidupan sehari-hari siswa ataupun permasalahan tersebut dapat dibayangkan oleh siswa. Implikasi dari hal tersebut maka, matematika tidak boleh diberikan kepada siswa dalam bentuk produk yang sudah jadi melainkan siswa harus dapat mengkontruksi dan menemukan sendiri konsep matematika tersebut melalui proses pembelajaran di kelas. Proses menerjemahkan setiap pemasalahan di dunia nyata maupun dapat dibayangkan siswa kedalam model matematika disebut matematisasi. Proses matematisasi dalam pembelajaran matematika realistik ada dua menurut Freudenthal (dalam Van Den Heuvel, 2003:12) yaitu matematisasi 
horizontal dan matematisasi vertikal. Dalam matematisasi horizontal siswa dituntut dapat memodelkan, merumuskan, dan mengidentifikasi masalah dengan caranya tersendiri, sedangkan matematisasi vertikal siswa diharapkan dapat menghaluskan dan menyesuaikan model matematika, mempresentasikan hubungan-hubungan dalam rumus, menggunakan model-model yang berbeda, merumuskan model matematika dan menggeneralisasikan hasil model matematika. Pemecahan masalah siswa akan dilatih melalui proses matematisasi horizontal dan matematisasi vertikal akan melatih penalaran siswa melalui proses generalisasi ataupun merumuskan model matematika. Selain itu saat matematisasi vertikal pemahaman konsep siswa akan dipertegas lagi sehingga melalui proses ini diharapkan akan terjadi pembelajaran yang bermakna. Implikasi dari semua ini diharapkan dapat mempengaruhi kemampuan pemecahan masalah matematika siswa. Menyadari hal tersebut, penelitian ini bertujuan untuk mendeskripsikan kemampuan pemecahan masalah matematika siswa kelas VII pada materi geometri yang dibelajarkan dengan PMR lebih baik daripada kemampuan pemecahan masalah matematika siswa yang belajar dengan PBM.

\section{METODE PENELITIAN}

Penelitian ini bertujuan untuk mendeskripsikan kemampuan pemecahan masalah matematika siswa kelas VII SMP N 1 Sukasada yang belajar dengan model PMR lebih baik daripada kemampuan pemecahan masalah matematika siswa yang belajar dengan PBM. Penelitian ini berjenis penelitian eksperimen semu, karena tidak semua variabel dan kondisi eksperimen dapat diatur dan dikontrol secara ketat. Penelitian ini menggunakan rancangan "Post-Test Only Control Group Design".

Tabel 1. Rancangan Penelitian

\begin{tabular}{ccc}
\hline Kelompok & Perlakuan & Post test \\
\hline Eksperimen & $\mathrm{X}_{1}$ & $\mathrm{Y}$ \\
\hline Pembanding & $\mathrm{X}_{2}$ & $\mathrm{Y}$ \\
\hline & & (Sugiyono, 2012)
\end{tabular}

Keterangan :

$\mathrm{X}_{1}=$ Perlakuan berupa penerapan PMR

$\mathrm{X}_{2}=$ Perlakuan berupa penerapan PBM

$\mathrm{Y}=$ post-test $\mathrm{untuk}$ masing-masing kelas

Penelitian ini dibagi menjadi dua kelompok yang menjadi sampel, yaitu kelompok eksperimen dan kelompok pembanding. Kelompok eksperimen merupakan kelas yang diberikan perlakuan berupa dengan PMR, sedangkan untuk kelompok pembanding adalah kelas yang diberikan perlakuan dengan PBM.

Populasi dalam penelitian ini adalah seluruh siswa kelas VII non unggulan di SMP N 1 Sukasada pada semester genap tahun ajaran 2017/2018. Populasi dalam penelitian ini berjumlah 211 orang yang tersebar dalam 7 kelas diluar kelas unggulan. Keterbatasan waktu dan biaya dalam penelitian ini, mengharuskan adanya penetapan sampel. Penetapan sampel dalam penelitian ini menggunakan teknik purposive random sampling, dikarenakan peneliti tidak dapat mengubah kelas yang sudah ada. Proses pengambilan sampel menghasilkan 2 kelas yaitu kelas VIIE dan VIIH yang kemudian dilakukan pengundian kembali untuk menentukan kelas eksperimen dan kelas pembanding. Teknik tersebut menghasilkan kelas VII E sebagai 
kelas pembanding dan VII H sebagai kelas eksperimen.

Variabel yang terlibat dalam penelitian ini ada dua yaitu: variabel bebas adalah variabel yang mempengaruhi variabel terikat nantinya. Variabel bebas dalam penelitian ini adalah pembelajaran matematika realistik yang diberlakukan di dalam kelas eksperimen dan pembelajaran berbasis masalah yang akan diberlakukan di dalam kelas pembanding, sedangkan untuk variabel terikat dalam penelitian ini adalah kemampuan pemecahan masalah matematika siswa kelas VII SMP N 1 Sukasada.

Penelitian ini menggunakan materi garis dan sudut, serta materi segitiga dan segiempat yang merupakan bagian dari materi semester genap kelas VII kurikulum 2013. Perangkat pembelajaran ini terdiri atas LKS untuk kelas eksperimen dan pembanding, serta RPP untuk kelas eksperimen dan pembanding. Penelitian dilakukan selama 8 kali pertemuan untuk kelas eksperimen dan kelas pembanding. Setelah mencapai 8 kali pertemuan dikelas eksperimen dan pembanding, maka pada pertemuan kesembilan dilakukan tes pemecahan masalah, baik untuk kelas eksperimen dan kelas pembanding. Posttest pada penelitian ini menggunakan tes essai yang telah dinyatakan valid dan reliabel dalam mengukur kemampuan pemecahan masalah matematika siswa. Proses penilaian menggunakan rubrik skor yang terlebih dahulu sudah disetujui pembimbing.

Pengujian validitas tes dalam penelitian ini menggunakan uji pakar dan uji validitas konstruk butir tes. Pada uji validitas pakar peneliti memohon masukan dari para ahli yakni dosen matematika yang kemudian diuji menggunakan uji Gregory. Pada uji validitas konstruk butir tes peneliti melakukan uji coba terhadap tes kemampuan pemecahan masalah matematika siswa di SMP N 3 Sawan, setelah diperoleh hasil tes kemudian dilakukan pengujian menggunakan uji korelasi product moment. Uji validitas menghasilkan soal-soal yang valid sebanyak 5 buah soal yang nantinya akan dijadikan soal post-test, kemudian soal yang valid tersebut diuji reliabelitasnya menggunakan uji Alpha cronbach.Melalui pengujian diperoleh bahwa koefisien reliabilitas tes adalah 0.836 , maka sesuai dengan kriteria pengujian, diperoleh soal post-test yang akan diujikan memiliki derajat reliabilitas tes tergolong sangat tinggi

Data skor tes kemampuan pemecahan masalah matematika siswa diperoleh dengan cara melakukan tes terhadap kelompok eksperimen dan kelompok pembanding. Hasil post-test diuji normalitasnya menggunakan uji Lilliefors dan uji homogenitasnya menggunakan uji Levene. Setelah didapatkan data yang berdistribusi normal dan homogen selanjutnya akan dilakukan uji hipotesis, uji hipotesis dalam penelitian ini menggunakan uji t-test satu pihak (pihak kanan). Uji hipotesis ini bertujuan untuk mengetahui apakah kemampuan pemecahan masalah matematika siswa yang dibelajarkan dengan PMR lebih baik daripada PBM.

\section{HASIL DAN PEMBAHASAN}

Analisis skor kemampuan pemecahan masalah matematika siswa dapat dilihat pada tabel dibawah ini 
Tabel 2. Analisis skor kemampuan pemecahan masalahmatematika siswa

\begin{tabular}{ccc}
\hline \multirow{2}{*}{ Variabel } & \multicolumn{2}{c}{ Post-Test } \\
\cline { 2 - 3 } & Eksperimen & Pembanding \\
\hline$n$ & 30 & 29 \\
\hline Mean & 13,4333 & 12,3793 \\
\hline Modus & 15 & 11 \\
\hline Median & 14 & 12 \\
\hline Varians & 5,35747 & 5,10099 \\
\hline S & 2,35307 & 2,25854 \\
\hline Skor Max & 18 & 17 \\
\hline Skor Min & 8 & 9 \\
\hline$<$ mean & 14 & 15 \\
\hline & &
\end{tabular}

Berdasarkan tabel diatas nampak bahwa rata-rata skor pemecahan masalah matematika siswa yang dibelajarkan menggunakan PMR lebih tinggi daripada rata-rata skor kemampuan pemecahan masalah matematika siswa yang dibelajarkan dengan PBM.

Proses pengujian normalitas terhadap skor post-test yang diperoleh untuk kelompok pembanding maupun kelompok eksperimen menghasilkan data yang berdistribusi normal. Pengujian menggunakan liliefors pada kelompok eksperimen menghasilkan $\mathrm{L}_{\text {hitung }}=$ 0,1546 dengan $\mathrm{L}_{\text {tabel }}=0,161$, berdasarkan kriteria pengujian jika $\mathrm{L}_{\text {hitung }}<\mathrm{L}_{\text {tabel }}$ maka data berdistribusi normal. Pengujian menggunakan liliefors pada kelompok pembanding menghasilkan $\mathrm{L}_{\text {hitung }}=$ 0,1458 dengan $\mathrm{L}_{\text {tabel }}=0,164$, berdasarkan kriteria pengujian jika $\mathrm{L}_{\text {hitung }}<\mathrm{L}_{\text {tabel }}$ maka data berdistribusi normal.

Pengujian homogenitas varians menggunakan uji levene, berdasarkan pengujian skor kemampuan pemecahan masalahmatematika siswadiperoleh nilai $W$ sebesar 0,017 dan pada tabel $F$ untuk signifikasi $5 \%$ dengan derajat pembilang sebesar 1 dan derajat penyebut sebesar 57, diperoleh nilai pada tabel $F$ sebesar 4,01. Nilai $W$ yang diperoleh jauh lebih kecil daripada nilai yang diperoleh pada tabel $F$. Sehingga dapat ditarik sebuah kesimpulan skor data kemampuan pemecahan masalah matematika siswa pada kelompok eksperimen dan kelompok pembanding memiliki varians yang homogen.

Berdasarkan proses pengujian data menggunakan uji normalitas dan uji homogenitas, telah diperoleh data skor kemampuan pemecahan masalah matematika siswa berdistribusi normal dan memiliki varian yang homogen. Selanjutnya akan dilakukan pengujian terhadap hipotesis dalam penelitian ini. Pengujian hipotesis menggunakan uji-t satu ekor yaitu ekor kanan dengan taraf signifikasi sebesar 0,05. Hasil pengujian dengan menggunakan uji-t dapat dilihat pada tabel 3 .

Nampak bahwa $t_{\text {hitung }}=1,76959$ dan $\mathrm{t}_{\text {tabel }}=1,67203$. Berdasarkan kriteria pengujian jika $t_{\text {hitung }}>t_{\text {tabel. }}$ maka $\mathrm{H}_{0}$ ditolak dan $\mathrm{H}_{1}$ diterima. Berdasarkan hal tersebut terindikasi bahwa kemampuan pemecahan masalah matematika siswa yang dibelajarkan dengan PMR lebih baik daripada kemampuan pemecahan masalah matematika siswa yang dibelajarkan dengan PBM. 
Tabel 3, Rangkuman Hasil Uji-t

\begin{tabular}{|c|c|c|c|c|c|c|c|}
\hline$\overbrace{\text { Kelompok }}^{\text {Uji t }}$ & $\mathrm{N}$ & $\mathrm{Dk}$ & $\bar{X}$ & $s_{i}^{2}$ & $s^{2}$ & $t_{\text {hitung }}$ & $t_{\text {tabel }}$ \\
\hline Eksperimen & 30 & \multirow{2}{*}{57} & 13,4333 & 5,1 & \multirow{2}{*}{5,231} & \multirow{2}{*}{1,76959} & \multirow{2}{*}{1,67203} \\
\hline Pembanding & 29 & & 12,3793 & 5,357 & & & \\
\hline
\end{tabular}

Melalui proses perhitungan menggunakan uji-t diperoleh hasil $t_{\text {hitung }}=$ 1,76959 dan untuk $t_{\text {tabel }}=1,67203$ dengan taraf signifikasi 0,05 . Berdasarkan kriteria pengujian, maka $H_{0}$ ditolak dan $H_{1}$ diterima, hal ini dikarenakan hasil perhitungan menggunakan uji-t memperoleh hasil $t_{\text {hitung }}>t_{\text {tabel }}$. Perhitungan ini juga menunjukkan bahwa, kemampuan pemecahan masalah matematika siswa yang mengikuti pembelajaran matematika realistik lebih baik daripada kemampuan pemecahan masalah matematika siswa yang mengikuti pembelajaran berbasis masalah. Fakot-faktor yang mendukung hasil penelitian tersebut berdasarkan temuan di lapangan dipaparkan sebagai berikut.

Proses pembelajaran di lapangan menunjukkan terdapat perbedaan respon siswa dalam mengikuti proses pembelajaran yang diamati melalui keantusiannya dalam pelaksanaan pembelajaran. Pada siswa yang mengikuti PMR cenderung antusias dalam mengerjakan LKS yang dibagikan oleh guru mata pelajaran matematika dan hampir setiap soal pada LKS dijawab oleh siswa, hal ini disebabkan setiap permasalahan yang disajikan dalam LKS PMR menuntut siswa melakukan aktivitas dalam proses pengerjaannya. PMR menekankan adanya aktivitas siswa dalam proses pembelajaran di mana siswa memiliki tanggungjawab dalam mengkontruksi setiap konsep yang dibelajarkan. Aktivitas saat pembelajaran diharapkan akan menimbulkan interaksi pada proses pembelajaran, baik itu guru dengan siswa, siswa dengan guru ataupun siswa dengan siswa, selain itu aktivitas ini akan meningkatkan motivasi belajar siswa. Astriyani (2015) menyatakan bahwa PMR berbantuan media pembelajaran manipulatif berpengaruh terhadap motivasi belajar siswa.

Pada proses pembelajaran siswa juga dituntut dapat mengkontruksi ulang setiap konsep matematika melalui permasalahan yang disajikan pada LKS, dan proses pembelajaran PMR didesain supaya menyenangkan bagi siswa sehingga siswa akan larut dalam proses pembelajaran. Proses pembelajaran yang menyenangkan dan menjadikan matematika sebagai aktivitas, akan menjadikan pembelajaran matematika lebih bermakna, sehingga akan berdampak kepada kemampuan pemecahan masalah matematika siswa nantinya. Menurut Pangestu (2016) melalui penelitiannya menemukan bahwa PMR memiliki pengaruh yang kuat terhadap suasana pembelajaran yang menyenangkan.

PBM siswa respon siswa cendrung kurang antusias dari pada PMR pada saat proses pembelajaran, hal ini dibuktikan dengan siswa yang mau mengacungkan tangan ketika guru mengajukan pertanyaan pada saat pembelajaran lebih sedikit daripada saat pembelajaran menggunakan PMR, dan banyaknya soal yang tidak terjawab pada LKS yang telah diberikan. Kurang antusiasnya siswa dalam mengerjakan LKS PBM ini dikarenakan 
pada pembelajaran berbasis masalah siswa cenderung hanya belajar mengenai materi yang ingin dipelajari dan mengabaikan setiap permasalahan yang tidak disukai walaupun telah diberikan motivasi oleh guru. Selain itu siswa cenderung kurang paham mengenai tujuan dari setiap permasalahan yang disajikan, dimana siswa hanya berfokus dalam memecahkan masalah tanpa dapat mengkontruksi ulang setiap konsep yang ingin ditanamkan dalam masalah tersebut kebentuk formal. Hasil yang sama juga ditemukan oleh Farahiya (2015) yang menemukan bahwa adanya respon positif siswa dalam proses pembelajaran yang dibelajarkan dengan RME, dimana rata-rata respon positif siswa yang dibelajarkan dengan RME sebesar 93,34\% cenderung lebih tinggi, daripada PBL dengan rata-rata respon positifnya sebesar 90,4\%. Selain itu Farahiya juga menemukan bahwa terdapat perbedaan yang signifikan antara RME dan PBL mengenai kemampuan komunikasi matematis siswa, dan disposisi matematis siswa.

Berdasarkan post-test yang diberikan, diperoleh mengenai analisis proses pemecahan masalah matematika yang dilakukan oleh siswa mulai dari mengidentifikasi permasalahan yang disajikan, melakukan perencanaan pemecahan masalah, sampai pada proses pemecahan permasalahan tersebut yang disajikan dalam tabel 4.

Tabel 4. Proses pemecahan masalah matematika siswa

\begin{tabular}{ccc}
\hline \multirow{2}{*}{ Indikator } & \multicolumn{2}{c}{ Presentase } \\
\cline { 2 - 3 } & eksperimen & pembanding \\
\hline Identifikasi masalah & $83,33 \%$ & $79,31 \%$ \\
\hline Perencanaan & $66,66 \%$ & $65,5 \%$ \\
\hline Penyelesaian masalah & $50 \%$ & $44,8 \%$ \\
\hline Rata-rata & $66,63 \%$ & $63,2 \%$ \\
\hline
\end{tabular}

Siswa yang dibelajarkan dengan PMR cenderung memiliki kreatifitas dalam proses pemecahan masalah, dan berusaha untuk mengkontruksi konsepnya sendiri. Siswa menggunakan simbol yang mereka bentuk sendiri dalam pengkontruksian konsepnya. Proses pengkontruksian siswa ini dilakukan pada tahap matematisasi horizontal dan diarahkan ke konsep formal melalui proses matematisasi vertikal. Pada tahap matematisasi horizontal ini terlihat kreatifitas siswa yang tinggi dalam mengkontruksi konsepnya sendiri. Proses pengkontruksian konsep pada siswa ini akan melatih proses berpikir kreatif dan kemampuan komunikasi matematisi siswa. hal ini juga didukung oleh penelitian yang dilakukan Nurhayati (2017) yang menemukan bahwa pembelajaran matematika realistik Indonesia efektif dalam meningkatkan kemampuan komunikasi matematis siswa. Komunikasi matematika yang baik serta dibarengi dengan pikiran kreatif yang ditimbulkan saat proses pembelajaran matematika realistik secara tidak langsung juga akan mempengaruhi kemampuan pemecahan masalah matematika siswa nantinya. Pekerjaan siswa yang dibelajarkan dengan PBM ada kecenderung mengikuti proses yang telah terdapat pada buku paket siswa, sehingga berdampak tidak optimalnya pembentukan pola pikir kreatif siswa. hal ini juga sejalan dengan hasil penelitian yang dilakukan oleh Imelda (2014) yang menemukan hasil penelitian yaitu kemampuan berpikir kreatif siswa yang dibelajarkan dengan pembelajaran matematika realistik lebih baik daripada pembelajaran berbasis masalah. Kemampuan berpikir kreatif siswa dapat menjadi landasan dalam membangun kemampuan siswa dalam memecahkan masalah. 
Pemahaman konsep siswa terhadap materi yang dibelajarkan akan mendukung kemampuan pemecahan masalah siswa nantinya. Pada PMR siswa dituntut untuk dapat mengkontruksi ulang konsep matematika melalui permasalahan realistik yang disajikan, sedangkan pada PBMproses pembelajarannya menggunakan permasalahan-permasalahan di dunia nyata yang memiliki tujuan mengkontruksi pengetahuan siswa. Cangkupan masalah yang disajikan dalam PMR lebih luas daripada cangkupan masalah yang disajikan dalam PBM. Cakupan permasalahan tersebut akan berpengaruh terhadap proses pengkontruksian konsep matematika siswa nantinya yang akhirnya bermuara kepada kemampuan pemecahan masalah siswa. menurut hasil penelitian yang dilakukan Nurdini (2017) melalui penelitiannya menemukan bahwa terdapat perbedaan pemahaman konsep dan self confidence antara siswa yang dibelajarkan dengan RME dan PBL. Berdasarkan hasil penelitiannya juga ditemukan bahwa pemahaman konsep dan self confidence yang dibelajarkan dengan RME lebih baik daripada yang dibelajarkan dengan PBL.

Perbedaan kemampuan pemecahan masalah matematika yang diperoleh oleh kelompok siswa yang dibelajarkan dengan pembelajaran matematika realistik dan pembelajaran berbasis masalah disebabkan oleh pada pembelajaran matematika realistik tidak hanya menekankan proses pemecahan masalah melalui matematisasi horizontal namun juga mengembangkan penalaran siswa melalui proses penyesuaian dan pengembangan model matematika, serta mengombinasikan berbagai model matematika yang terjadi saat proses matematisasi vertikal pada proses matematisasi vertikal. Hal ini juga didukung oleh penelitian yang dilakukan oleh Gusnarsi(2017) yang menemukan hasil penelitian yaitu RME memiliki pengaruh yang tinggi terhadap kemampuan penalaran matematis siswa. Pada penelitiannya juga ditemukan bahwa aktivitas siswa dalam pembelajaran RME termasuk golongan aktif dan motivasi belajar siswa yang dibelajarkan dengan RME termasuk kedalam katagori tinggi. Penalaran siswa yang baik akan mempengaruhi proses pemecahan masalah siswa nantinya.

Temuan dalam penelitian ini juga didukung oleh penelitian yang serupa yang dilakukan oleh Fitriana(2016) yang menghasilkan temuan sebagai berikut terdapat pengaruh dari pendekatan pembelajaran yang digunakan baik itu RME ataupun PBM terhadap hasil belajar matematika siswa, Fitriana juga menemukan hasil penelitian yaitu rata-rata nilai tes hasil belajar siswa yang dibelajarkan dengan RME lebih tinggi daripada nilai tes hasil belajar siswa yang dibelajarkan dengan PBL. Siswa yang dibelajarkan dengan RME memiliki rata-rata nilai hasil belajar sebesar 80,89 dan yang dibelajarkan dengan PBL memiliki rata-rata sebesar 75,305 atau selisih nilainya sebesar 5,585. Selisih yang diperoleh oleh Fitriana ini tidak jauh berbeda dengan selisih nilai yang diperoleh pada penelitian ini yaitu sebesar 5,27.

Berdasarkan hasil penelitian dan penelitian terkait yang telah dipaparkan, maka dapat diketahui bahwa kemampuan pemecahan masalah matematika siswa yang dibelajarkan dengan PMR lebih baik daripada kemampuan pemecahan masalah matematika siswa yang dibelajarkan dengan PBM. 


\section{SIMPULAN}

Berdasarkan rumusan masalah, tujuan, hasil analisis, dan pembahasan yang telah diuraikan di depan, maka dapat ditarik kesimpulan mengenai kemampuan pemecahan masalah matematika siswa pada materi garis dan sudut, serta segitiga dan segiempat di kelas VII SMP N 1 Sukasada yang dibelajarkan dengan PMR dan PBM yaitu, kemampuan pemecahan masalah matematika siswa yang dibelajarkan dengan PMR lebih baik daripada kemampuan pemecahan masalah yang dibelajarkan dengan PBM.

\section{DAFTAR PUSTAKA}

Arends, Richard I. 2007. Learning to Teach Seventh Edition. New York: The. McGraw Hill Companies.

Arikunto, S. 2002. Dasar-dasar Evaluasi Pendidikan. Jakarta: Bumi Aksara.

Astriyani, Arlin. 2015 "Pengaruh Pendekatan Pendidikan Matematika Realistik Berbantuan Bahan Manipulatif Terhadap Motivasi Belajar Matematika " Fibonacci: Jurnal Pendidikan Matematika dan Matematika. Vol. 1(1), pp: 28-42.

Bedilius.2016. Pengaruh Pendidikan Matematika Realistik terhadap Kemampuan Pemecahan Masalah Matematika Ditinjau dari Kemampuan Numerik Siswa SMP N 1 Cibal. Tesis tidak diterbitkan. Singaraja: Program Pascasarjana Universitas Pendidikan Ganesha.

Dahar, R. W. 1989. Teori-Teori Belajar. Jakarta: Erlangga.

Farahiya, Cut Izzah, 2015. Perbedaan Peningkatan Kemampuan Komunikasi dan Disposisi Matematis antara Siswa yang Diberi Pembelajaran Problem Based Learning dengan Siswa yang Diberi Pembelajaran Realistic Mathematics Education di MTsN Ulumul Qur'an Langsa. [Online] Tersedia : http://digilib.unimed.ac.id/8209/8/3.\%20ABST RAK.pdf. [16 April 2018].

Fitriana, Dyah,Ayu. 2016. Penelitian Hasil Belajar Matematika dengan Pendekatan Realistic Mathematics Education dan Problem Based Learning Ditinjau dari Motivasi Belajar Kelas XI IPA Sekolah Menengah Atas. [Online] Tersedia: http://eprints.ums.ac.id/48430/2/02.\%20NASKAH\%20PUBLIKASI.pdf $\left[\begin{array}{ll}16 & \text { April }\end{array}\right.$ 2018].

Gusnarsi. Desi, Utami. Citra, Wahyuni. Rika, 2017. "Pengaruh Model Pembelajaran Realistic Mathematics Education (RME) Terhadap kemampuan Penalaran Matematis Siswa pada Materi Lingkaran”. Jurnal Pendidikan Matematika Indonesia. Vol.2 (1), pp: 3236.

Hartono, Yusuf. 2014. Matematika: Strategi Pemecahan Masalah. Yogyakarta: Graha Ilmu. 
Imelda. Sinaga, 2014. Perbedaan Kemampuan Berpikir Kreatif Siswa SMA yang Dibelajarkan dengan Pendekatan Pembelajaran Matematika Realistik dan Pembelajaran Berbasis Masalah (PBM) Pada Siswa Kelas X Sma Negeri 8 T.A 2013/2014. [Online] Tersedia: http://digilib.unimed.ac.id /11872/5/409411018\%20 ABSTRAK.pdf [16 April 2018].

Kemendikbud. 2016. Permendikbud No.23 tentang Standar Penilaian Pendidikan. Jakarta: Kementrian Pendidikan dan Kebudayaan.

Kemendikbud. 2017. Rekapan Nilai UN. [Online] Tersedia: https://puspendik.kemdikbud.go.id/hasil-un/ [2 Februari 2018].

Mahayukti, G.A, Suarsana, I M, Wijaya, I G. A. P, 2013. "Pembelajaran Matematika Realistik untuk Meningkatkan Daya Matematik dan Prestasi Belajar Siswa". Jurnal Pendidikan dan Pengajaran. Vol.46 (1), pp: 38-46.

Murniati, L.D, Candiasa, I M, Kirna I M, 2013. "Pengembangan Perangkat Pembelajaran Matematika Realistik untuk Meningkatkan Kemampuan Pemecahan Masalah Siswa SMP”. Jurnal Pendidikan dan Pengajaran. Vol.46 (2), pp: 114-124.

Nurdini, Sophi. 2017. Kemampuan Pemahanam Konsep dan Seft Confidence Melalui Model Realistic Mathematics Education dan Model Problem Based Learning Terhadap siswa SMP. [Online] Tersedia: http://repository. unpas.ac.id/14844/1/artikel\%20tesis.pdf [17 April 2018].

Nurhayati. Nunu, 2017 "Pengembangan Perangkat Bahan Ajar pada Pembelajaran Matematika Realistik Indonesia untuk Meningkatkan Kemampuan Komunikasi Matematis Siswa" Fibonacci: Jurnal Pendidikan Matematika dan Matematika. Vol. 3 (2), pp: 121-136.

Pangestu, Prayogo. \& Utami PS, Utami. 2016 "Pengaruh Pendidikan Matematika Realistik Terhadap Suasana Belajar Yang Menyenangkan Pada Pelajaran Matematika Sekolah Dasar" Fibonacci: Jurnal Pendidikan Matematika dan Matematika. Vol. 2 (2), pp: 5871.

Sawyer, W.W. 1991. Mathematician's Delight. USA : Penguin Group USA.

Sugiyono. 2007. Statistika Untuk Penelitian. Bandung: CV Alfabeta.

Suharta, I Gusti, Putu. 2017. "Pembelajaran Matematika Realistik di SD”. Makalah Dalam: Pelatihan Pembelajaran Matematika Realistik bagi Guru SD, 11 Agustus 2017.

Suherman, E.1993. Evaluasi Hasil Belajar dan Belajar Matematika. Jakarta: Depdikbud. 
I Wayan A, I Gusti N P,dan I Made S : Komparasi Kemampuan Pemecahan Masalah Matematika Antara PMR dan PBM Pada Materi Geometri SMP Kelas VII

FIBONACCI : Jurnal Pendidikan Matematika dan Matematika. Vol. 4 (1), pp: 47-60.

Van den Heuvel-Panhuizen, 2003.“The Didactical Use of Models in Realistic Mathematics Education: an Example From a Longitudinal Trajectory on Percentage". Educational Studies in Mathematics. Vol. 54, pp: 341-37.

Winarni Pudji, Candiasa. I M, Marhaeni. A.A.I.N. 2013. Pengaruh Pendekatan Kontekstual Berbasis Asesmen Kinerja terhadap Hasil Belajar Matematika Ditinjau dari Bakat Numerik pada Siswa Kelas V SDN 1 dan SDN 2 Gianyar di Gugus 1 Kecamatan Gianyar. [Online] Tersedia: http://119.252. 161.254/ejournal/index.php/jurnal_ep/ article/download676/461 [15 Oktober 2017]. 
FIBONACCI : Jurnal Pendidikan Matematika dan Matematika

Volume 4 No.1 Bulan Juni Tahun 2018 